\title{
PENGEMBANGAN PERANGKAT PEMBELAJARAN TEMATIK DALAM PENINGKATAN KARAKTER, MOTIVASI, DAN PRESTASI BELAJAR SISWA SEKOLAH DASAR
}

\author{
Kustiwi Nur Utami, Ali Mustadi \\ Program Pascasarjana, Universitas Negeri Yogyakarta \\ Email: nurutami2009@gmail.com, aly_uny@yahoo.com
}

\begin{abstract}
Abstrak: Penelitian ini bertujuan untuk menghasilkan perangkat pembelajaran tematik integratif yang layak dan efektif untuk meningkatkan karakter santun dan tanggung jawab, motivasi intrinsik, dan prestasi belajar siswa. Penelitian ini merupakan penelitian dan pengembangan yang terdiri atas sepuluh tahap, yaitu penelitian dan pengumpulan data, perencanaan, pengembangan produk awal, uji coba awal, revisi hasil uji coba awal, uji coba lapangan, revisi produk hasil uji coba lapangan, uji pelaksanaan lapangan, penyempurnaan produk akhir, dan diseminasi produk. Subjek uji coba berjumlah 3 siswa SD Glagahan pada uji coba awal, dan 9 orang siswa SD Tunjungan pada uji coba lapangan yang dipilih berdasarkan kriteria tinggi, sedang, dan rendah. Hasil penelitian ini berupa perangkat pembelajaran meliputi: silabus, RPP, LKS, media pembelajaran, dan soal tes prestasi. Hasil penilaian ahli materi dan ahli media untuk menguji kevalidan perangkat pembelajaran dinyatakan bahwa perangkat pembelajaran valid dan berkategori baik. Hasil uji coba menunjukkan bahwa produk yang dikembangkan layak serta memenuhi kriteria praktis dan efektif dalam meningkatkan karakter, motivasi, dan prestasi belajar siswa. Pembelajaran dengan produk yang dikembangkan mampu meningkatkan karakter santun dan tanggung jawab, motivasi intrinsik, dan prestasi belajar siswa.
\end{abstract}

Kata kunci: perangkat pembelajaran tematik, karakter, motivasi, prestasi belajar.

\section{DEVELOPING THEMATIC LEARNING KITS TO IMPROVE THE CHARACTERS, MOTIVATION, AND LEARNING ACHIEVEMENT OF THE ELEMENTARY SCHOOL}

\begin{abstract}
This study aims to produce integrated thematic learning kits capable of improving students' characters, especially politeness and responsibility, learning motivation, especially intrinsic learning motivation, and learning achievement. This was a research and development study consisting of ten stages, namely research and data collection, planning, preliminary product development, preliminary tryout, revision based on the preliminary tryout results, field tryout, revision based on the field tryout results, field implementation testing, product finalization, and product dissemination. The tryout subjects were Grade II students of the elementary school, consisting of 3 students of SD Glagahan in the preliminary tryout and 9 students of SD Tunjungan in the field tryout, selected based on the criteria for students from the upper, moderate, and lower groups. The research product is integrated thematic learning kits consisting of a syllabus, lesson plans, student worksheets, learning media, and learning achievement tests. The results of the assessment by the material expert and the learning media expert show that the developed learning kits are valid and good and appropriate to be used for thematic learning at the elementary school. The results of the tryout show that the developed learning kits are appropriate and capable of improving students' characters, motivation, and learning achievement.
\end{abstract}

Keywords: thematic learning kits, characters, motivation, learning achievemen

\section{PENDAHULUAN}

Pendidikan merupakan sebuah usaha untuk mewariskan pengetahuan dari generasi ke generasi yang berlangsung sepanjang hidup manusia. Hal ini dilakukan supaya generasi penerus lebih berbudaya dan berkualitas dalam hidup bermasyarakat. Dukungan terhadap pendidikan yang menghasilkan insan berbudaya dan berkualitas diwujudkan UNESCO dalam empat pilar pendidikan yaitu learning to know (belajar mengetahui), learning to be (belajar menjadi dirinya sendiri), learning to do (belajar bekerja), dan learning to live together (belajar hidup bersama).

Pendidikan terbentuk melalui proses interaksi antara siswa dan siswa, siswa dan sumber belajar, dan siswa dan guru yang dapat terjadi di dalam lingkungan keluarga, sekolah, dan masyarakat. Dalam lingkungan keluarga, orang tua berperan sebagai guru bagi anaknya. Melalui proses interaksi dengan orang tua, anak mendapatkan konsep dasar pengetahuan, nilainilai moral dan karakter yang kemudian dikembangkan melalui pendidikan di lingkungan sekolah dan masyarakat. 
Melalui proses pendidikan ini diharapkan dapat membentuk watak bangsa yang bermartabat. Sebagaimana tujuan pendidikan yang terdapat dalam Undang-Undang Nomor 20 Tahun 2003 tentang Sistem Pendidikan Nasional pada Bab II Pasal 3. Pada undangundang tersebut dinyatakan bahwa pendidikan memiliki fungsi dan tujuan yaitu pendidikan nasional berfungsi mengembangkan kemampuan dan membentuk watak serta peradaban bangsa yang bermartabat dalam rangka mencerdaskan kehidupan bangsa, bertujuan untuk berkembangnya potensi siswa agar menjadi manusia yang beriman dan bertakwa kepada Tuhan Yang Maha Esa, berakhlak mulia, sehat, berilmu, cakap, kreatif, mandiri dan menjadi warga negara yang demokratis serta bertanggung jawab. Sejalan dengan Undang-undang tersebut, tujuan pendidikan antaralain membentuk watak dari siswa yang dididik. Pembentukan watak dipengaruhi oleh penanaman nilai karakter pada siswa.

Nilai karakter penting sekali dimiliki siswa kelas awal sekolah dasar. Hal ini sesuai dengan pendapat Mustadi (2011: 6) yakni mengingat pentingnya penanaman karakter di usia sekolah dasar dan mengingat usia sekolah dasar merupakan masa awal pembentukan diri, maka penanaman karakter yang baik di usia sekolah dasar merupakan hal yang sangat penting untuk dilakukan. Kurangnya penanaman nilai-nilai karakter seperti karakter santun dan tanggung jawab dapat mempengaruhi pencapaian prestasi siswa. Jurnal penelitian Benninga, J.S., et. all. (2003) yang berjudul "The Relationship of Character Education Implementation and Academic Achievement in Elementary Schools" dijelaskan bahwa sekolah yang menerapkan pendidikan karakter memiliki nilai akademis yang lebih tinggi dari tahun-tahun sebelum diterapkan pendidikan karakter di sekolah tersebut. Dalam penelitian tersebut disebutkan bahwa sekolah yang menerapkan pendidikan karakter memiliki nilai akademis yang lebih tinggi dibandingkan sebelum menerapkan pendidikan karakter. Dengan demikian, ada keterkaitan antara karakter dan prestasi siswa.

Karakter rendah dapat mempengaruhi rendahnya pencapaian prestasi akademik. Dengan meningkatkan karakter melalui pembelajaran yang terintegrasi dengan pendekatan pendidikan karakter dapat meningkatkan pencapaian prestasi akademik siswa. Siswa yang berkarakter akan menunjukkan motivasi belajar yang tinggi. Hal ini disebabkan karena pengaruh dari internalisasi nilai karakter akan membentuk sikap positif siswa. Sikap positif tersebut di antaranya tumbuhnya motivasi untuk belajar yang muncul dari dalam diri siswa.

Motivasi merupakan salah satu faktor penting dalam proses belajar yang dapat memberikan dampak positif pada prestasi siswa. Motivasi belajar dapat terbentuk melalui keterlibatan guru dan orang tua dengan berbagai cara dalam mendorong motivasi siswa. Pemberian hadiah yang dapat berupa benda atau ucapan bernilai positif (pujian) terhadap perilaku positif yang ditunjukkan siswa dapat meningkatkan motivasi siswa. Motivasi yang timbul dari luar diri siswa disebut sebagai motivasi ekstrinsik.

Pemberian motivasi ekstrinsik seperti hadiah dan penghargaan pada akhirnya akan mencapai titik jenuh yaitu saat siswa tidak termotivasi lagi dengan hadiah atau penghargaan yang diberikan oleh guru atau orang tua. Jacobsen (2009: 12) menyebutkan bahwa faktor motivasi yang didasarkan pada penghargaan-penghargaan ekstrinsik karena menyenangkan orang lain dan menerima reward hanya menghasilkan keuntungan pembelajaran jangka pendek. Dengan demikian, penting sekali bagi guru untuk membantu siswa menumbuhkan motivasi instrinsik supaya siswa memiliki keinginan untuk menghadapi, mengeksplorasi, dan mengatasi tantangantantangan dalam proses belajar.

Internalisasi nilai karakter melalui pembelajaran di kelas yang sekaligus meningkatkan motivasi dan prestasi belajar siswa memerlukan suatu rancangan pembelajaran. Rancangan pembelajaran ini meliputi perangkat pembelajaran yang mengintegrasikan karakter sebagai pengembangan sikap siswa dan skenario pembelajaran yang memungkinkan tercapainya peningkatan motivasi dan prestasi belajar siswa.

Perangkat pembelajaran merupakan sarana yang dapat memberikan kemudahan guru dalam melaksanakan praktik pembelajaran di kelas. Selain itu dalam perangkat pembelajaran terdapat strategi untuk belajar dan mengajar. Perangkat pembelajaran yang baik adalah yang direncanakan dengan seksama. Perangkat pembelajaran yang dikembangkan dalam penelitian ini adalah perangkat pembelajaran dengan pendekatan pembelajaran tematik integratif.

Pembelajaran tematik integratif merupakan model pembelajaran terpadu menggunakan pendekatan antar bidang studi. 
Model ini dilakukan dengan cara menggabungkan bidang studi dengan cara menetapkan prioritas kurikuler dan menemukan keterampilan, konsep, dan sikap yang saling tumpang tindih di dalam beberapa bidang studi (Fogarty, 1991: 75). Melalui model pembelajaran tematik integratif memungkinkan siswa baik secara individu maupun kelompok dapat secara aktif menggali dan menemukan konsep serta prinsip-prinsip keilmuan secara holistik, bermakna, dan otentik. Penilaian belajar siswa dalam pembelajaran tematik integratif dilakukan dengan asesmen autentik, yaitu asesmen yang melibatkan siswa di dalam tugas-tugas autentik yang bermanfaat, penting, dan bermakna (Hosnan, 2014: 388). Pendekatan saintifik diaplikasikan dalam perangkat pembelajaran untuk memberikan scaffolding terhadap tingkat berpikir siswa untuk mencapai tahap berpikir tingkat tinggi. Selain itu melalui pendekatan saintifik ini dapat membentuk sikap siswa dan bertujuan mengembangkan good character.

Pengembangan perangkat pembelajaran tematik integratif dalam penelitian ini untuk mencapai peningkatan karakter, motivasi, dan prestasi belajar siswa. Pengembangan perangkat pembelajaran yang dilakukan merujuk pada beberapa prinsip Developmentally Appropriate Practice (DAP) yang dikemukakan oleh Bredekamp dan Copple (1997) bahwa dalam pembelajaran guru memperhatikan perubahan yang terjadi pada setiap aspek perkembangan siswa meliputi perkembangan fisik, kognitif, emosi, minat, bakat, serta sosial, dan pembelajaran disesuaikan pada: (1) teori perkembangan anak, (2) identifikasi kekuatan individual dan penilaian otentik terhadap kebutuhan masing-masing anak, dan (3) latar belakang budaya anak seperti komunitas, riwayat keluarga, dan struktur keluarga. Siswa dipandang sebagai individu yang utuh (the whole child) dari empat aspek, yaitu pengetahuan (knowledge), keterampilan (skills), sifat alamiah (dispositions), dan perasaan (feelings).

Berdasarkan hasil need analysis melalui wawancara terhadap guru kelas II di beberapa SD di Gugus Caturharjo pada bulan Februari tahun 2015 diperoleh gambaran bahwa dalam proses pembelajaran masih menggunakan pendekatan teacher centered. RPP belum terintegrasi dengan pendidikan karakter, peningkatan motivasi, dan peningkatan prestasi siswa. LKS yang digunakan belum merupakan hasil pengembangan guru dan tampilannya kurang menarik. Variasi pembelajaran yang kurang membuat siswa seringkali bosan dengan pelajaran. Proses pembelajaran belum menimbulkan motivasi intrinsik siswa untuk belajar. Hal ini ditandai dengan kurangnya antusias siswa dengan tugas yang diberikan guru. Prestasi belajar masih belum optimal. Beberapa siswa masih belum mencapai prestasi rata-rata di kelas.

Peningkatan karakter siswa, khususnya peningkatan karakter santun dan tanggung jawab belum optimal. Beberapa siswa belum dapat bertanggung jawab terhadap tugas-tugas yang diberikan guru. Selain itu ada beberapa siswa yang belum bisa menunjukkan sikap santun terhadap teman seperti memanggil nama teman dengan nama julukan dan hal ini sudah menjadi kebiasaan. Dengan demikian, guru memerlukan perangkat pembelajaran yang dapat digunakan sebagai panduan mengajar yang terintegrasi peningkatan karakter, motivasi, dan prestasi belajar.

\section{METODE}

Penelitian ini menggunakan model penelitian dan pengembangan atau Research and Development $(R \& D)$. Borg \& Gall (2003: 259) mendefinisikan penelitian dan pengembangan merupakan bentuk pengembangan berdasarkan hasil penelitian yang digunakan untuk merancang produk dan tata cara baru, yang kemudian diujicobakan, dievaluasi, dan diperhalus secara sistematis sampai mendapatkan kriteria khusus secara efektif, berkualitas, atau standar yang sama.

Penelitian ini dilaksanakan di dua sekolah yakni SD Glagahan dan SD Tunjungan, yang dipilih sebagai lokasi penelitian setelah dilakukan observasi dan wawancara yang menunjukkan bahwa sekolah tersebut membutuhkan perangkat pembelajaran yang mengintegrasikan peningkatan karakter, motivasi, dan prestasi belajar siswa. Waktu penelitian dilaksanakan pada semester 1 tahun ajaran 2015-2016.

Subjek penelitian adalah guru dan siswa kelas II SD Tunjungan dan SD Glagahan. Uji coba awal dilakukan terhadap 3 orang siswa dan 1 orang guru dari SD Glagahan. Uji coba lapangan dilakukan terhadap 9 orang siswa dan 1 orang guru SD Tunjungan. Uji pelaksanaan lapangan dilakukan terhadap keseluruhan siswa kelas II SD Tunjungan dan SD Glagahan.

Prosedur yang digunakan merujuk pada langkah-langkah dalam research and development (R\&D) sebagaimana yang dikemukakan oleh Borg \& Gall (1983) meliputi 
sepuluh langkah. Kesepuluh langkah pengembangan tersebut antaralain: (1) Research and information collecting (penelitian dan pengumpulan informasi), (2) Planning (perencanaan), (3) develop premilinary form of product (pengembangan produk awal), (4) premilinary field testing (uji coba lapangan awal), (5) main product revision (revisi hasil uji coba awal), (6) main field testing (uji coba lapangan), (7) operational product revision (revisi produk hasil uji coba lapangan), (8) operational field testing (uji pelaksanaan lapangan), (9) final product revision (penyempurnaan produk akhir), (10) dissemination and implementation (diseminasi dan implementasi).

Dari kesepuluh langkah pengembangan dari Borg \& Gall (1983) ini dikelompokkan menjadi empat tahap pengembangan, yaitu: (1) tahap eksplorasi yang meliputi penelitian dan pengumpulan informasi, (2) tahap pengembangan draf dan penilaian ahli meliputi perencanaan dan pengembangan produk awal, (3) tahap uji coba produk meliputi uji coba awal, revisi hasil uji coba awal, uji coba lapangan, revisi produk hasil uji coba lapangan, dan uji pelaksanaan lapangan, (4) tahap finalisasi dan diseminasi meliputi penyempurnaan produk akhir, desiminasi dan implementasi produk. Pada penelitian ini, peneliti hanya melaksanakan sampai tahap uji pelaksanaan lapangan karena keterbatasan waktu uji coba. Selanjutnya hasil revisi ini merupakan produk akhir dari penelitian.

Uji coba yang dilakukan bertujuan untuk mengembangkan perangkat pembelajaran tematik-integratif untuk peningkatan karakter, motivasi, dan prestasi belajar siswa yang layak dan mengetahui keefektifan dari produk yang dikembangkan. Uji coba yang dilakukan meliputi tiga tahap, yaitu uji coba awal, uji coba lapangan dan uji pelaksanaan lapangan.

Data penelitian ini berupa data validasi ahli mengenai kelayakan produk yang dikembangkan berupa perangkat pembelajaran meliputi silabus, RPP, LKS, media pembelajaran, dan soal tes prestasi belajar, angket penilaian guru terhadap perangkat pembelajaran yang dikembangkan, angket respons siswa, data hasil pengamatan peningkatan karakter dan motivasi intrinsik, dan hasil tes prestasi belajar.

Teknik pengumpulan data yang digunakan meliputi: wawancara, penilaian produk oleh ahli, tes, observasi, dan angket. Instrumen penelitian ini adalah pedoman wawancara, instrumen lembar validasi ahli, pedoman observasi, soal tes prestasi belajar, dan angket.

Data yang diperoleh melalui kegiatan uji coba diklasifikasikan menjadi dua, yaitu data kualitatif dan data kuantitatif. Data kualitatif berupa masukan, koreksi, saran, dan kritik yang diberikan oleh ahli materi dan ahli media pembelajaran terhadap produk yang dikembangkan. Data ini dianalisis dengan teknik interactive analysis yang meliputi reduksi data, data display, dan penarikan kesimpulan (Miles \& Huberman, 2014: 15-21). Data ini selanjutnya sebagai bahan revisi produk perangkat pembelajaran.

Data kuantitatif diperoleh melalui instrumen validasi, hasil tes, observasi, dan angket dan dianalisis dengan statistik untuk mengetahui kelayakan dan keefektifan produk. Prosedur analisis data untuk kelayakan perangkat pembelajaran tematik integratif dilakukan dengan langkah-langkah antara lain: (a) Data berupa skor dari para ahli diperoleh melalui lembar validasi. Selanjutnya mentabulasi semua data yang diperoleh dari validator untuk setiap komponen, subkomponen dari butir penilaian yang tersedia dalam instrumen penilaian, dan menghitung skor total rata-rata dari setiap komponen; (b) Total skor aktual yang diperoleh kemudian dikonversikan menjadi data kuantitatif skala lima. Produk dinyatakan layak apabila mendapat nilai minimal "C".

Untuk memperoleh kriteria kelayakan produk, skor yang diperoleh kemudian dikonversikan menjadi nilai pada skala 5, dengan acuan tabel 1 (Sukardjo, 2005: 55) sebagai berikut.

Tabel 1. Konversi Skor Aktual Menjadi Skor Skala Lima Berdasarkan Simpangan Baku (SB)

\begin{tabular}{ccc}
\hline Nilai & \multicolumn{3}{c}{ Skor } \\
\hline $\mathrm{A}$ & $\mathrm{X} \overline{\mathrm{i}}+1,80 . \mathrm{SBi}$ & $<\mathrm{X}$ \\
$\mathrm{B}$ & $\mathrm{X} \overline{\mathrm{i}}+0,60 . \mathrm{SBi}$ & $<\mathrm{X} \leq \mathrm{X} \overline{\mathrm{i}}+1,80 . \mathrm{SBi}$ \\
$\mathrm{C}$ & $\mathrm{X} \overline{\mathrm{i}}-0,60 . \mathrm{SBi}$ & $<\mathrm{X} \leq \mathrm{X} \overline{\mathrm{i}}+0,60 . \mathrm{SBi}$ \\
$\mathrm{D}$ & $\mathrm{X} \overline{\mathrm{i}}-1,80 . \mathrm{SBi}$ & $<\mathrm{X} \leq \mathrm{X} \overline{\mathrm{i}}-0,60 . \mathrm{SBi}$ \\
$\mathrm{E}$ & & $\mathrm{X} \leq \mathrm{X} \overline{\mathrm{i}}-1,80 . \mathrm{SBi}$ \\
\hline
\end{tabular}

Keterangan:

$\mathrm{X} \overline{\mathrm{i}}=$ rerata skor ideal $=1 / 2$ (skor maksimum ideal + skor minimum ideal).

$\mathrm{SBi}=$ Simpangan baku skor ideal $=1 / 6$ (skor maksimum ideal - skor minimum ideal) $\mathrm{X}=$ skor aktual.

\section{HASIL DAN PEMBAHASAN}


Hasil pengembangan tahap pertama adalah deskripsi tahap eksplorasi. Pada tahap ini dilakukan analisis kebutuhan untuk mendapatkan informasi yang akurat tentang kebutuhan siswa dan guru. Berdasarkan hasil pengamatan dan wawancara guru maka perlu dikembangkan perangkat pembelajaran yang sesuai dengan karakteristik siswa.

Pada tahap pengembangan draf dipilih pendekatan pembelajaran tematik integratif yang digunakan dalam perangkat pembelajaran. Hal ini berdasarkan hasil studi literatur bahwa kelas awal sekolah dasar lebih tepat menggunakan pendekatan pembelajaran tersebut. Melalui pendekatan ini siswa akan belajar secara holistik, otentik, bermakna, dan aktif.

Perangkat pembelajaran juga terintegrasi dengan pendekatan saintifik untuk meningkatkan motivasi intrinsik dan kemampuan tingkat berpikir siswa. Pendekatan saintifik ini berorientasi pada kegiatan discovery dan inquiri terbimbing yang dapat memberikan lingkungan belajar menyenangkan bagi siswa, mengarahkan siswa menjadi mandiri, self-directed, dan bertanggung jawab.

Tabel 2. Data Kevalidan dari Ahli Materi dan Ahli Media Pembelajaran

\begin{tabular}{clcl}
\hline No. & Komponen perangkat pembelajaran & Total skor & Kriteria \\
\hline 1 & Silabus & 65 & cukup baik \\
2 & RPP & 100 & baik \\
3 & LKS & 48 & baik \\
4 & Media & 71 & baik \\
5 & Soal tes prestasi belajar & 61 & baik \\
\hline
\end{tabular}

Data hasil validasi media pembelajaran oleh ahli media diperoleh jumlah skor 48. Penilaian ahli terhadap media pembelajaran setelah dikonversi mendapat nilai "A" dengan kriteria "sangat baik, produk layak digunakan untuk pembelajaran setelah direvisi. Data hasil penilaian silabus oleh ahli materi diperoleh jumlah skor 65. Penilaian ahli materi terhadap silabus setelah dikonversi mendapat nilai "C" dengan kriteria "cukup baik, silabus layak digunakan setelah direvisi. Data hasil penilaian RPP oleh ahli materi diperoleh jumlah skor 100. Hasil penilaian setelah dikonversi mendapat nilai "B" dengan kriteria "baik, RPP layak digunakan untuk pembelajaran setelah direvisi. Data hasil penilaian LKS oleh ahli materi diperoleh jumlah skor 71. Penilaian ahli materi terhadap LKS setelah dikonversi mendapat nilai "B" dengan kriteria "baik", LKS layak digunakan untuk pembelajaran setelah direvisi. Data hasil penilaian soal tes prestasi belajar oleh ahli materi diperoleh jumlah skor 61. Penilaian ahli materi terhadap perangkat
Melalui kegiatan pembelajaran dengan pendekatan saintifik ini motivasi, karakter, dan prestasi ditingkatkan.

Media pembelajaran merupakan bagian terpenting dari perangkat pembelajaran di kelas awal. Siswa pada kelas awal menurut Piaget masih dalam tahap operasional konkret, sehingga melalui manipulasi benda konkret siswa belajar konsep-konsep abstrak. Selain itu, berdasarkan tingkat pengalaman belajar Brunner, siswa kelas awal akan lebih banyak mendapat pengalaman dengan belajar melalui pengalaman langsung (enactive) dengan objek belajar.

Produk awal perangkat pembelajaran yang sudah dirancang kemudian dievaluasi oleh ahli materi dan ahli media pembelajaran. Data yang diperoleh dalam penelitian pengembangan ini terdiri dari: (1) data hasil validasi ahli materi dan ahli media pembelajaran, (2) data uji coba awal, (3) data uji coba lapangan, (4) data uji pelaksanaan lapangan.

Tabel 2 berikut ini adalah data hasil penilaian kevalidan produk yang dilakukan oleh ahli materi dan ahli media pembelajaran. pembelajaran berupa soal tes prestasi belajar setelah dikonversi mendapat nilai " $\mathrm{B}$ " dengan kriteria "baik, soal tes prestasi belajar layak digunakan setelah direvisi.

Penilaian perangkat pembelajaran oleh praktisi ditinjau dari aspek materi dan media pembelajaran. Praktisi atau guru kelas memberikan penilaian serta masukan/saran untuk perbaikan. Data hasil penilaian silabus oleh guru kelas diperoleh jumlah skor 67, termasuk dalam kategori "Cukup Baik". Data hasil penilaian RPP diperoleh jumlah skor 103, termasuk dalam kategori "Baik". Data hasil penilaian LKS diperoleh jumlah skor 73, termasuk dalam kategori "sangat baik". Data hasil penilaian silabus diperoleh jumlah skor 50, termasuk dalam kategori "sangat baik". Data hasil penilaian soal tes prestasi belajar diperoleh jumlah skor 62, termasuk dalam kategori "baik".

Uji Coba Awal 
Uji coba awal dilakukan dengan desain one-shot case study. Uji ini diterapkan pada tiga orang siswa kelas II. Penilaian pada uji ini menggunakan nilai posttest. Data yang diperoleh pada uji coba awal berupa keterlaksanaan pembelajaran, respons siswa, dan pengamatan peningkatan karakter, motivasi, dan prestasi belajar. Data ini sebagai bahan untuk merevisi produk perangkat pembelajaran. Pengamatan aspek pelaksanaan pembelajaran terdiri dari tiga indikator yaitu kegiatan awal, kegiatan inti, dan kegiatan akhir. Kegiatan awal terdiri dari 6 pernyataan, jumlah skor penilaian dari observer 11. Kegiatan inti terdiri dari 8 pernyataan, Jumlah skor penilaian dari observer 12. Kegiatan akhir terdiri dari 6 pernyataan, jumlah skor penilaian dari observer 9. Jumlah skor keseluruhan penilaian kegiatan awal, kegiatan inti, dan kegiatan akhir dari observer adalah 34. Setelah dikonversi, penilaian observer termasuk kategori "baik".

Tabel 3. Respon Siswa Terhadap Perangkat Pembelajaran Tematik Integratif

\begin{tabular}{llll}
\hline Aspek yang dinilai & Rata-rata jumlah skor & Skor rata-rata keseluruhan & Kategori \\
\hline LKS & 12,75 & 4,25 & Sangat Baik \\
Media & 13,00 & 4,33 & Sangat baik \\
Proses pembelajaran & 12,5 & 4,17 & Baik \\
Rata-rata & 12,75 & 4,25 & Sangat Baik \\
\hline
\end{tabular}

Berdasarkan tabel 3 diperoleh respons siswa terhadap perangkat yang dikembangkan diketahui bahwa rata-rata jumlah skor penilaian terhadap LKS adalah 12,75 dengan skor ratarata keseluruhan 4,25 masuk dalam kategori "Sangat Baik". Rata-rata jumlah skor penilaian terhadap media adalah 13,00 dengan skor ratarata keseluruhan 4,33 masuk dalam kategori "Sangat baik". Rata-rata jumlah skor penilaian terhadap proses pembelajaran adalah 12,5 dengan skor rata-rata keseluruhan 4,17 masuk dalam kategori "Baik". Skor rata-rata keseluruhan penilaian terhadap LKS, media, dan proses pembelajaran adalah 4,25 termasuk kriteria "Sangat Baik".

Hasil pengamatan terhadap kegiatan siswa menunjukkan karakter santun siswa sangat baik dengan skor 3,6, karakter tanggung jawab sangat baik dengan skor 4,3, motivasi Tabel 4. Respons Siswa Terhadap Perangkat Pembelajaran Tematik Integratif

\begin{tabular}{llll}
\hline Aspek yang dinilai & Rata-rata jumlah skor & Skor rata-rata keseluruhan & Kategori \\
\hline LKS & 16,67 & 4,17 & Baik \\
Media & 17,11 & 4,28 & Sangat baik \\
Proses pembelajaran & 8,11 & 4,06 & Baik \\
Rata-rata & 41,89 & 4,19 & Baik \\
\hline
\end{tabular}

Berdasarkan tabel 4 diperoleh data respons siswa yaitu rata-rata jumlah skor penilaian terhadap LKS adalah 16,67 dengan skor rata-rata keseluruhan 4,17 masuk dalam kategori "Baik". Rata-rata jumlah skor penilaian terhadap Media adalah 17,11 dengan skor rata-rata keseluruhan 4,28 masuk dalam kategori "Sangat baik". Rata-rata jumlah skor penilaian terhadap proses pembelajaran adalah 8,11 dengan skor rata-rata keseluruhan 4,06 masuk dalam kategori "Baik". Skor rata-rata keseluruhan penilaian terhadap LKS, media, intrinsik siswa sangat baik dengan skor 4,7, dan prestasi belajar siswa rata-rata 7,17.

\section{Uji Coba Lapangan}

Setelah produk hasil uji coba awal direvisi, kemudian diujicobakan lagi. Desain uji coba hampir sama dengan uji coba awal. Hanya jumlah siswa ditambah menjadi 9 orang yang mewakili kelompok tinggi, kelompok sedang, dan kelompok rendah.

Pelaksanaan proses pembelajaran pada uji coba awal dilaksanakan satu kali pertemuan. Penilaian keterlaksanaan RPP selama proses pembelajaran dilakukan oleh satu observer. Jumlah skor keseluruhan penilaian kegiatan awal, kegiatan inti, dan kegiatan akhir dari observer adalah 34. Setelah dikonversi, penilaian observer termasuk kategori "baik". dan proses pembelajaran adalah 4,19 termasuk kriteria "Baik".

Hasil pengamatan kegiatan siswa menunjukkan karakter santun siswa sangat baik dengan skor 3,4, karakter tanggung jawab sangat baik dengan skor 3,7, motivasi intrinsik siswa sangat baik dengan skor 4, dan prestasi belajar siswa rata-rata 7,5.

Uji Pelaksanaan Lapangan

Uji pelaksanaan lapangan dilakukan untuk memperoleh data keefektifan perangkat pembelajaran yang dikembangkan. Uji ini 
menggunakan dua kelas, satu kelas eksperimen dan satu kelas kontrol. Proses pembelajaran kelas eksperimen menggunakan perangkat pembelajaran hasil pengembangan dan proses pembelajaran kelas kontrol menggunakan perangkat pembelajaran yang biasa digunakan guru.
Perangkat pembelajaran tematik integratif yang telah direvisi berdasarkan masukan validator dan hasil uji sebelumnya kemudian diujicobakan di kelas eksperimen pada siswa kelas II SD Tunjungan yang berjumlah 25 anak.

Tabel 5. Hasil Keterlaksanaan Pembelajaran dengan RPP Tematik Integratif Kelas Eksperimen

\begin{tabular}{lcccll}
\hline Pembelajaran KE & \multicolumn{2}{c}{ Penilaian observer } & & Rata-rata & Kategori \\
\cline { 2 - 3 } & I & II & & \\
\hline Pertemuan 1 & 34 & 34 & & 34 & Baik \\
Pertemuan 2 & 37 & 35 & & 36 & Sangat Baik \\
Pertemuan 3 & 40 & 37 & & 38,5 & Sangat Baik \\
Jumlah & 111 & 106 & & 108,5 & \\
Rata-rata & 37 & 35,33 & 36,17 & Baik \\
\hline
\end{tabular}

Berdasarkan data penilaian observer terhadap keterlaksanaan pembelajaran dengan RPP Tematik Integratif pada pertemuan 1 diketahui rata-rata penilaian observer I adalah 34 dan rata-rata penilaian observer II adalah 34 . Sehingga skor rata-rata keseluruhan penilaian observer pada pertemuan 1 adalah 34 masuk dalam kategori "Baik".

Pada pertemuan 2 rata-rata penilaian observer I adalah 37 dan rata-rata penilaian observer II adalah 35, sehingga skor rata-rata keseluruhan penilaian observer pada pertemuan 2 adalah 36 masuk dalam kategori "baik".

Pada pertemuan 3 rata-rata penilaian observer I adalah 40 dan rata-rata penilaian observer II adalah 37. Sehingga rata-rata keseluruhan penilaian observer adalah 38,5.
Skor keterlaksanaan pembelajaran ini masuk dalam kategori "sangat baik".

Rata-rata penilaian observer I untuk keterlaksanaan pembelajaran pertemuan 1, pertemuan 2, dan pertemuan 3 adalah 37 masuk kategori "baik", sedangkan rata-rata penilaian observer II untuk keterlaksanaan pembelajaran pertemuan 1 , pertemuan 2 , dan pertemuan 3 adalah 35,33 masuk kategori "Baik".

Skor rata-rata keseluruhan penilaian observer terhadap keterlaksanaan pembelajaran pertemuan 1 , pertemuan 2 , dan pertemuan 3 adalah 36,17 masuk kategori "Baik". Dengan demikian, perangkat pembelajaran tematik integratif yang dikembangkan penulis ini efektif untuk digunakan di sekolah dasar.

Tabel 6. Respons Siswa Terhadap Perangkat Pembelajaran Tematik Integratif

\begin{tabular}{llll}
\hline Aspek yang dinilai & Rata-rata jumlah skor & Skor rata-rata keseluruhan & Kategori \\
\hline LKS & 112,75 & 4,51 & Sangat baik \\
Media & 111 & 4,44 & Sangat baik \\
Proses pembelajaran & 105,5 & 4,22 & Sangat Baik \\
Rata-rata & 109,75 & 4,39 & Sangat baik \\
\hline
\end{tabular}

Berdasarkan data respons siswa pada uji pelaksanaan lapangan diketahui bahwa jumlah skor rata-rata penilaian terhadap LKS adalah 112,75 dengan skor rata-rata keseluruhan 4,51 masuk dalam kategori "sangat baik". Rata-rata jumlah skor penilaian terhadap media adalah 111 dengan skor rata-rata keseluruhan 4,44 masuk dalam kategori "sangat baik". Jumlah skor rata-rata penilaian terhadap proses pembelajaran adalah 105,5 dengan skor ratarata keseluruhan 4,22 masuk dalam kategori "sangat baik". Skor rata-rata keseluruhan penilaian terhadap LKS, media, dan proses pembelajaran adalah 4,39 termasuk kriteria "sangat baik".

Berikutnya adalah data hasil pengamatan karakter dan motivasi. Data hasil pengamatan ditunjukkan pada tabel 7 berikut ini. Berdasarkan data pada tabel 7 dapat disimpulkan bahwa karakter santun, tanggung jawab, motivasi intrinsik kelas eksperimen lebih tinggi dari skor yang diperoleh kelas kontrol. Pembelajaran dengan perangkat yang dikembangkan efektif dalam meningkatkan karakter dan motivasi intrinsik siswa.

Tabel 7. Skor Rata-rata Hasil Pengamatan Karakter Santun, Karakter Tanggung jawab, dan Motivasi Intrinsik 


\begin{tabular}{llllll}
\hline No. & Aspek & KE & Kategori & KK & Kategori \\
\hline 1 & Karakter Santun & 3,31 & Sangat baik & 3,28 & Sangat baik \\
2 & Karakter Tanggung jawab & 3,17 & Sangat Baik & 3,08 & Sangat baik \\
3 & Motivasi Intrinsik & 3,25 & Sangat baik & 3,12 & Baik \\
\hline
\end{tabular}

Data hasil belajar berupa hasil tes prestasi belajar yang diperoleh dari nilai pre-test dan post-test pada uji pelaksanaan lapangan. Data ini digunakan untuk mengetahui pengaruh perangkat pembelajaran pada kelas eksperimen. Ringkasan data hasil tes prestasi belajar pada kelas eksperimen dan kelas kontrol dapat dilihat pada tabel 8 .

Tabel 8. Ringkasan Data Hasil Tes Prestasi Belajar Kelompok Eksperimen dan Kelompok Kontrol

\begin{tabular}{llllllll}
\hline No & Aspek & \multicolumn{1}{l}{ KE } & \multicolumn{5}{c}{$K K$} \\
\cline { 3 - 7 } & Pre-test & post-test & $\begin{array}{l}\text { Peningkatan } \\
(\mathrm{g})\end{array}$ & Pre-test & post-test & Peningkatan \\
\hline 1 & Nilai tertinggi & 9 & 9,5 & 0,5 & 9 & 9 & 0 \\
2 & Nilai terendah & 4 & 6 & 0,33 & 4 & 6 & 0,33 \\
3 & Rata-rata & 7,02 & 8,2 & 0,40 & 7,08 & 7,88 & 0,25 \\
\hline
\end{tabular}

Pada kelompok eksperimen diperoleh nilai tertinggi pretest 9 naik menjadi 9,5 pada posttest. Nilai ini mengalami peningkatan sebesar 0,5. Nilai terendah pretest 4 naik menjadi 6 pada posttest. Nilai ini mengalami peningkatan sebesar 0,33 . Rata-rata pre-test 7,02 naik menjadi 8,2 pada posttest. Kenaikan

nilai rata-rata sebesar 0,40 berdasarkan berdasar gain standar, menurut kriteria peningkatan hasil belajar Hake (1998: 65), masuk kategori "hasil belajar sedang".

Pada kelompok kontrol diperoleh nilai tertinggi pre-test 9 naik menjadi 9 pada postest. Nilai ini mengalami peningkatan sebesar 0 .
Nilai terendah pre-test 4 naik menjadi 6 pada pos-test. Nilai ini mengalami peningkatan sebesar 0,33. Rata-rata pre-test 7,08 naik menjadi 7,88 pada pos-test. Kenaikan nilai ratarata ini sebesar 0,25 berdasarkan gain standar, menurut kriteria peningkatan hasil belajar Hake (1998: 65), masuk kategori "hasil belajar rendah".

Selanjutnya hasil analisis tes prestasi belajar diperoleh kesimpulan bahwa sebelum perlakuan kedua kelompok memiliki kemampuan awal yang sama, sedangkan setelah perlakuan terdapat perbedaan kemampuan. Hasil uji beda rata-rata ini dapat dilihat pada tabel 9.

Tabel 9. Ringkasan Hasil Uji Perbedaan Rata-Rata Hasil Tes Prestasi Belajar

\begin{tabular}{cccccccc}
\hline Data & Kelompok & $\mathrm{N}$ & $\mathrm{df}$ & $\mathrm{t}_{\text {hitung }}$ & $\mathrm{t}_{\text {tabel }}$ & Sig. $(\mathrm{p})$ & Keterangan \\
\hline Pretest & $\mathrm{KE}$ & 25 & 48 & $-0,176$ & 2,064 & 0,861 & $\mathrm{H}_{0}$ diterima \\
& $\mathrm{KK}$ & 25 & & & & & \\
$\mathrm{~g}$ (Gain & $\mathrm{KE}$ & 25 & 48 & 4,383 & 2,064 & 0,000 & $\mathrm{H}_{0}$ ditolak \\
Standar) & $\mathrm{KK}$ & 25 & & & & & \\
\hline
\end{tabular}

Berdasarkan tabel 9 dapat diketahui bahwa harga $t_{\text {hitung }}$ pretest adalah $-0,176$ dengan tingkat signifikansi 2,064 karena $t_{\text {hitung }}(-0,176)$ $>-t_{\text {tabel }}(24 ; 0.025) \quad(-2,064)$ maka $\mathrm{H}_{0}$ diterima. Berdasarkan perhitungan ini dapat disimpulkan bahwa tidak ada perbedaan kemampuan awal siswa sebelum perlakuan.

Hasil uji $\mathrm{t}$ terhadap peningkatan nilai siswa ( $\mathrm{g}$ ) diperoleh harga $\mathrm{t}$ hitung sebesar 4,383 dengan tingkat signifikansi 2,064. Karena nilai $\mathrm{t}$ hitung $(4,383)>\mathrm{t}$ tabel ${ }_{(24 ; 0.025)}(2,064)$ maka $\mathrm{H}_{0}$ ditolak. Maka dapat disimpulkan bahwa terdapat perbedaan yang signifikan hasil belajar antara kelas yang diberi perlakuan pembelajaran menggunakan perangkat pembelajaran tematik integratif dengan kelas yang tidak diberi perlakuan yang sama.

Berdasarkan data dan hasil analisis yang telah dilakukan menunjukkan adanya peningkatan karakter, motivasi, dan prestasi belajar. Hal ini disebabkan perangkat pembelajaran tematik integratif meliputi silabus, RPP, LKS, media pembelajaran, dan soal tes prestasi belajar dikembangkan sesuai dengan karakteristik siswa serta mengintegrasikan metode dan strategi pembelajaran yang dapat meningkatkan karakter, motivasi, dan prestasi siswa efektif dan memudahkan guru dalam mencapai tujuan pembelajaran. 
Beberapa penelitian yang telah dilakukan Wawan \& Mustadi (2015), Qodriyah \& Wangid (2015), dan Waridah \& Aman (2015) membuktikan perangkat pembelajaran yang terintegrasi dengan penanaman nilai karakter dapat efektif meningkatkan karakter siswa. Qodriyah \& Wangid (2015: 13) menguatkan hasil penelitian ini bahwa pembelajaran dengan menggunakan SSP terintegrasi dengan karakter terbukti efektif dalam mengembangkan karakter siswa. SSP (Subject Specific Pedagogy) tersebut memiliki karakteristik mengandung unsur-unsur karakter kejujuran, dan kepedulian, sehingga pengembangan dua bidang karakter utama bagi siswa usia SD yakni karakter saintifik, karakter sosial dan humanis siswa dapat berkembang dengan baik, serta pembelajaran akan berlangsung lebih efektif dan efisien karena perangkat termasuk dalam media pembelajaran yang dibutuhkan sudah tersedia dalam SSP ini (Qodriyah \& Wangid, 2015: 12).

Karakteristik RPP pada penelitian ini yang memuat peningkatan karakter, motivasi, dan prestasi belajar. Peningkatan karakter tercapai melalui aktivitas guru dan siswa dalam pembelajaran diantaranya dengan kegiatan guru bercerita/mendongeng, guru mengontrol sikap kurang berkarakter dengan teguran, melalui pemberian contoh-contoh dan keteladanan, melalui aktivitas belajar siswa, dan melalui pengamalan karakter dalam keseharian siswa di sekolah. Kegiatan pembelajaran dalam RPP ini selaras dengan pendekatan penerapan karakter Kirschenbaum (Zuchdi, 2011: 23-28) yaitu inkulkasi atau penanaman (inculcation), keteladanan (modelling), fasilitasi (facilitation), dan pengembangan keterampilan akademik dan sosial (skill building).

Peningkatan motivasi tercapai melalui aktivitas belajar yang berpusat pada siswa sehingga memupuk sumber motivasi intrinsik (Schunk, Pintrich, \& Meece, 2010: 264-267) yaitu tantangan (challenge), keingintahuan (curiosity), kontrol (control), dan fantasi (fantasy). Siswa akan termotivasi secara intrinsik apabila diberikan aktivitas yang menantang, pemberian tugas dengan kesukaran menengah, membangkitkan rasa keingintahuan siswa, memberikan siswa rasa kontrol terhadap hasil-hasil akademis dengan memberikan berbagai pilihan aktivitas, dan menyajikan aktivitas yang melibatkan siswa dalam fantasi atau situasi tiruan melalui berbagai simulasi dan permainan.

Peningkatan prestasi belajar dilakukan dengan mengintegrasikan pendekatan saintifik dalam proses pembelajaran. Melalui pendekatan ini, siswa mengembangkan kemampuan berpikir tingkat tinggi. Pendekatan ilmiah meliputi kegiatan mengamati (observing), menanya (questioning), mencoba (experimenting), menalar/mengolah (associating) dan mengomunikasikan (Hosnan, 2014: 38). Melalui proses saintifik ini karakter siswa juga dibentuk. Selain itu, pengondisian suasana belajar yang positif mendukung pencapaian prestasi belajar yang tinggi. Sebagaimana yang dikemukakan Rathus (2014: 439) menjelaskan "achievement is enhanced when teacher expect students to master the curriculum, allocate most of the available time to academic activities, and manage the classroom environment effectively".

Maksud dari penjelasan ini adalah prestasi belajar siswa dapat ditingkatkan ketika guru menginginkan siswa dapat menguasai materi, mengalokasikan sejumlah waktu untuk kegiatan pembelajaran, dan mengatur lingkungan kelas secara efektif.

Selanjutnya dijelaskan pula oleh Rathus (2014: 439) bahwa "Achievement is high in classrooms that have a pleasant, friendly athmosphere ...". Maksud dari penjelasan ini bahwa prestasi belajar siswa yang tinggi dapat dicapai di kelas yang memiliki lingkungan pembelajaran yang menyenangkan, dan ramah.

Produk perangkat pembelajaran berupa media pembelajaran yang dikembangkan memberi dampak pada peningkatan prestasi siswa. Hal ini sejalan dengan simpulan hasil penelitian yang dilakukan Mardati \& Wangid (2015: 12) bahwa ada pengaruh yang signifikan setelah menggunakan media pada proses pembelajaran. Pengaruh tersebut yakni terdapat peningkatan hasil belajar siswa sesudah menggunakan media. Selain itu, penggunaan media dalam pembelajaran sesuai dengan teori Bruner yakni dalam proses belajar terdapat tiga pengalaman antara lain pengalaman langsung (enactive), pengalaman piktorial/gambar (iconic), dan pengalaman abstrak (symbolic). Hal ini juga sesuai dengan teori kognitif Piaget yakni anak memasuki tahap operasional kongkrit pada usia 7 tahun dan berakhir pada usia 12 tahun.

Karakteristik LKS dalam penelitian ini memuat peningkatan karakter, motivasi, dan prestasi belajar siswa. Muatan karakter terintegrasi dalam materi, sedangkan faktor motivasional terletak pada sajian yang menarik.

Hasil pengamatan karakter, motivasi, dan prestasi ini juga menunjukkan bahwa prestasi belajar dipengaruhi oleh banyak faktor, yaitu: (1) faktor internal, (2) faktor eksternal, 
dan (3) faktor pendekatan belajar. Faktor internal dalam penelitian ini adalah motivasi intrinsik dan karakter. Menurut Fogarty (2009: 4) emosi siswa turut diperhitungkan dalam membentuk suasana lingkungan belajar yang nyaman. Siswa memiliki motivasi intrinsik tinggi serta berkarakter akan mudah dalam mencapai prestasi belajar yang tinggi.

Karakter siswa yang terbentuk dengan baik akan tampak pada perilakunya yang menanggapi secara positif terhadap setiap aktivitas pembelajaran. Sikap positif ini mendukung terciptanya suasana belajar yang kondusif. Lingkungan belajar merupakan faktor eksternal yang mempengaruhi prestasi siswa. Disamping itu faktor pendekatan pembelajaran yang digunakan dalam penelitian ini dapat membingkai pembelajaran dapat sesuai dengan perkembangan siswa. Pembelajaran yang sesuai dengan perkembangan siswa dapat mengoptimalkan pencapaian prestasi siswa.

Pada hasil penelitian juga dapat dilihat adanya hubungan keterkaitan antara motivasi, karakter, dan pencapaian prestasi belajar. Peningkatan karakter, motivasi, dan prestasi belajar saling berkaitan satu sama lain. Peningkatan karakter memberi dampak pengiring bagi peningkatan motivasi dan prestasi siswa. Siswa berkarakter akan menunjukkan sikap positif untuk belajar hingga tercipta lingkungan belajar yang kondusif yang memungkinkan pencapaian prestasi belajar yang tinggi. Sikap ini merupakan aspek penting terbentuknya motivasi intrinsik. Siswa yang memiliki motivasi belajar yang tinggi dapat mempengaruhi pencapaian prestasi di sekolah. Sebagaimana penelitian Abd-El-Fattah \& Patrick (2011: 106) disebutkan bahwa “... achievement motivation orientations can affect students' academic achievement and interest." Artinya, motivasi berprestasi dapat memberi dampak pada prestasi dan minat belajar.

\section{PENUTUP}

Simpulan

Berdasarkan data dan hasil penelitian diperoleh kesimpulan bahwa: (1) produk perangkat pembelajaran tematik integratif yang dikembangkan secara umum layak digunakan sebagai sumber belajar untuk kelas II SD. Hal ini dapat dilihat dari hasil validasi ahli materi dan ahli media pembelajaran yakni silabus mendapat skor 65 kategori cukup baik, RPP mendapat skor 100 kategori baik, LKS mendapat skor 71 kategori baik, media mendapat skor 48 kategori sangat baik, dan soal tes prestasi belajar mendapat skor 61 kategori baik; (2) Produk yang dikembangkan memiliki keefektifan dalam peningkatan karakter, motivasi, dan prestasi belajar siswa. Hal ini ditinjau dari hasil pengamatan terhadap karakter dan motivasi serta hasil tes prestasi belajar pada tiap tahap uji coba produk.

\section{Peningkatan Karakter}

Pada karakter santun peningkatan yang terjadi yakni siswa menyimak dengan baik, siswa menghargai orang lain, siswa berbicara dengan bahasa halus, siswa memanggil teman dengan nama sebenarnya, dan siswa minta ijin setiap akan keluar kelas selama pembelajaran berlangsung.

Pada karakter tanggung jawab peningkatan yang terjadi yakni siswa mengumpulkan tugas tepat waktu, siswa rapi dalam mengerjakan tugas, siswa tekun belajar, siswa tuntas dalam menyelesaikan tugas, siswa mengerjakan tugas secara mandiri, dan siswa masuk kelas dengan tertib.

\section{Peningkatan Motivasi}

Pada motivasi intrinsik peningkatan yang terjadi siswa senang bila diberi tugas, siswa senang bertanya, siswa senang menyelesaikan tugas yang diberikan, siswa kreatif, dan siswa gigih dalam menyelesaikan tugas.

\section{Peningkatan Prestasi Belajar}

Peningkatan prestasi belajar ditinjau dari hasil tes. Berdasarkan hasil analisis tes prestasi belajar siswa untuk kelas kontrol diperoleh ratarata skor pretest 7,08 dan skor post test 7,88. Pada kelas eksperimen diperoleh skor pretest 7,02 dan post test 8,2. Peningkatan skor kelas kontrol berdasarkan gain standar 0,25 dan kelas eksperimen 0,40. Peningkatan prestasi kelas eksperimen lebih tinggi dari kelas kontrol. Dengan demikian perangkat yang dikembangkan dapat meningkatkan prestasi belajar siswa.

Saran

Saran pemanfaatan, desiminasi dan pengembangan lebih lanjut yakni: (1) Pengembangan perangkat pembelajaran tematik integratif untuk meningkatkan karakter, motivasi, dan prestasi belajar siswa kelas I SD sudah diuji kevalidan, kepraktisan, dan keefektifannya, maka disarankan kepada guru untuk menggunakan perangkat ini sebagai pedoman dalam pelaksanaan pembelajaran yang terintegrasi dengan strategi dan metode peningkatan karakter santun dan tanggung 
jawab, motivasi intrinsik, dan prestasi belajar siswa; (2) Produk hasil pengembangan diharapkan dapat didesiminasikan di sekolah lain khususnya kelas II SD yang memiliki karakteristik yang sama dengan sekolah tempat uji coba dilaksanakan serta dapat dikembangkan lebih lanjut oleh guru agar lebih sesuai dengan karakteristik sekolah.

\section{UCAPAN TERIMA KASIH}

Dengan mengucap syukur kepada Allah SWT. tulisan ini dapat terselesaikan dan dapat dimuat di Jurnal Pendidikan Karakter edisi ini. Dalam kesempatan ini, penulis mengucapkan terima kasih yang setulus-tulusnya kepada dewan redaksi Jurnal Pendidikan Karakter yang telah melakukan penyuntingan terhadap tulisan ini hingga akhirnya dimuat di edisi sekarang ini.

\section{DAFTAR PUSTAKA}

Abd-El-Fattah, S. M. \& Patrick, R. R. 2011. The relationship among achievement motivation orientations, achievement goals, and academic achievement and interest: A multiple mediation analysis. Australian Journal of Educational \& Developmental Psychology, (11), 91 110.

Benninga, J. S. et. all. 2003. The relationship of character education implementation and academic achievement in elementary schools. Journal of Research in Character Education, (1), 19-32.

Bredekamp, S, \& Copple, C. 1997. Developmentally appropriate practice in early childhood programs (Rev Ed). Washington DC: The National Association for the Education of Young Children.

Fogarty, R. 1991. The mindful school: How to integrate the curricula. Illinois: IRI/ Skylight Publishing.

Fogarty, R. 2009. How to integrate the curricula, third ed. California: Corwin.

Gall, M.D., Gall, J.P. and Borg, W.R. 2003. Educational research: An introduction. New York: Pearson Education Inc.
Hake, R. R. 1998. Interactive-engagement vs traditional methods: A six thousandstudent survey of mechanics test data for introductory physics courses. American Association of Physics Teacher, (66), 64-74.

Hosnan. 2014. Pendekatan saintifik dan kontekstual dalam pembelajaran abad 21. Jakarta: Ghalia Pustaka.

Jacobsen, D. A., Eggen, P., \& Kauchak, D. 2009. Methods for teaching: Metodemetode pengajaran meningkatkan belajar siswa TK-SMA. (Terjemahan Achmad Fawaid \& Khoirul Anam). New Jersey: Pearson Education Inc. (Buku asli diterbitkan tahun 2009).

Mardati, A., \& Wangid, M. 2015. Pengembangan media permainan kartu gambar dengan teknik make a match untuk kelas I SD. Jurnal Prima Edukasia, (3), 120 - 132. Retrieved from http://journal.uny.ac.id/index.php/ ipe/ article/view/6532/6228

Miles, M. B. \& Huberman, A. M. 2014. Analisis data kualitatif (Terjemahan Tjetjep Rohendi Rohidi). Jakarta: UIPress. (Buku Asli diterbitkan tahun 1984).

Mustadi, A. 2011. Pendidikan karakter berwawasan sosiokultural (Sociocultural based character education) di Sekolah Dasar, Daerah Istimewa Yogyakarta (DIY). Dinamika Pendidikan: Majalah ilmu pendidikan, FIP UNY, (18), 1-15.

Peraturan Menteri Pendidikan Nasional Nomor 41, Tahun 2007, tentang Standar Proses untuk Satuan Pendidikan Dasar dan Menengah.

Qodriyah, S., \& Wangid, M. 2015. Pengembangan SSP tematik integratif untuk membangun karakter kejujuran dan kepedulian siswa SD kelas II. Jurnal Prima Edukasia, (3), 177 - 189. Retrieved from http://journal.uny.ac.id/ index.php/jpe/article/view/7222/6225

Rathus, S. A. 2014. Childhood \& adolescence voyages in development. New Jersey: Wadsworth Cengange Learning. 
Schunk, D. H., Pintrich, P. R., \& Meece, J. L. 2010. Motivation in education: Theory, Research, and applications, third edition. New Jersey: Pearson Education.

Setyawan, W., \& Mustadi, A. 2015. Pengembangan SSP tematik-integratif untuk membangun karakter disiplin dan kreatif siswa kelas I SD. Jurnal Prima Edukasia, (3), 108-119. Retrieved from http://journal.uny.ac.id/index.php/ jpe/article/view/4072/3525.

Sukardjo. 2005. Kumpulan materi evaluasi pembelajaran. Yogyakarta: PPs UNY

Undang-Undang RI Nomor 20, Tahun 2003, tentang Sistem Pendidikan Nasional.

Waridah, W., \& Aman, A. 2015. Pengembangan perangkat pembelajaran tematik-integratif tema menghargai jasa pahlawan berbasis sosiocultural di sekolah dasar. Jurnal Prima Edukasia, (3), 213-226. Retrieved from http://journal.uny.ac.id/index.php/jpe/ article/view/6465

Zuchdi, D., dkk. 2011. Panduan implementasi pendidikan karakter terintegrasi dalam pembelajaran dan pengembangan kultur sekolah. Yogyakarta: UNY Press. 